\title{
Karakteristik Kuantitatif Sapi Bali Menggunakan Analisis Komponen Utama di Kabupaten Merangin dan Muaro Jambi, Provinsi Jambi
}

\author{
Quantitative Characteristics of Bali Cattle Using Principle Component Analysis \\ in Merangin and Muaro Jambi Regency, Jambi Province
}

\section{Gushairiyanto dan Depison*}

\author{
Program Studi Peternakan Fakultas Peternakan Universitas Jambi \\ Jl. Jambi-Ma. Bulian KM 15 Mendalo Darat Jambi 36361 Indonesia \\ *Corresponding e-mail : depison.nasution@unja.ac.id
}

\begin{abstract}
S
This study was aimed to determine the quantitative characteristics of Bali cattle using principal component analysis in Merangin and Muaro Jambi Regencies, Jambi Province. Data collected are quantitative characteristics including; body weight, body weight gain, body length, shoulder height, chest circumference, chest height, chest width, hip height, canon circumference, and hip-width of Bali cattle in both locations. The material of this research was Bali cattle age $I_{1}(1-2)$ years. The method used in this study was a survey method. The sampling technique was purposive sampling. The number of samples collected as many as 120 heads each district 60 tails consisting of 30 males, and 30 females. The t-test was used to analyze differences in quantitative characteristics. Principal component analysis (PCA) was applied to show determinants of body size, and shape of Bali cattle. The results of this study showed that body weight, body weight growth, and body size measurements of male and female Bali cattle were not significantly different $(\mathrm{P}>0.05)$, meanwhile, body weight, weight gain and body size measurements of male, and female Bali cattle among two districts were significantly different $(\mathrm{P}<0.05)$. The determining factor for the body size of Bali cattle in the Merangin Regency and Muaro Jambi was the chest circumference and the determinant of body shape was body length.
\end{abstract}

Keywords: main component analysis, quantitative characterization, Bali cattle

\begin{abstract}
ABSTRAK
Tujuan penelitian ini, untuk mengetahui karakteristik kuantitatif sapi Bali menggunakan analisis komponen utama di Kabupaten Merangin dan Muaro Jambi Provinsi Jambi. Data yang dihimpun adalah karakteristik kuantitatif meliputi; bobot badan, pertambahan bobot badan, panjang badan, tinggi pundak, lingkar dada, dalam dada, lebar dada, tinggi pinggul, lingkar kanon dan lebar pinggul sapi Bali di kedua lokasi. Materi penelitian ini adalah sapi Bali Umur $\mathrm{I}_{1}(1-2)$ tahun. Metode penelitian survei, teknik pengambilan sampel secara purpossive sampling. Jumlah sampel yang dihimpun sebanyak 120 ekor masing masing kabupaten 60 ekor yang terdiri dari 30 ekor jantan dan 30 ekor betina. Uji t digunakan untuk menganalisis perbedaan karakteristik kuantitatif. Analsisi Komponen Utama digunakan untuk menentukan faktor penentu ukuran dan bentuk sapi Bali. Hasil penelitian menunjukkan bahwa bobot badan, pertambahan bobot badan dan ukuran tubuh sapi Bali jantan dan betina antara kedua kabupaten berbeda tidak nyata $(\mathrm{P}>0,05)$, namun bobot badan, pertambahan bobot dan dan ukuran ukuran tubuh sapi Bali Jantan dan betina di kedua kabupaten berbeda nyata $(\mathrm{P}<0,05)$. Faktor penentu ukuran tubuh sapi Bali di Kabupaten Merangin dan Kabupaten Muaro Jambi adalah Lingkar Dada, sedangkan penentu bentuk tubuh adalah panjang badan.
\end{abstract}

Kata kunci: analisi komponen utama, karakterisasi kuantitatif, sapi Bali

\section{PENDAHULUAN}

Potensi pengembangan sapi lokal di Indonesia sangat besar, sehingga perlu upaya peningkatan mutu genetik dalam rangka pelestariannya dimasa yang akan datang. Di antara beberapa sapi lokal yang ada di Indonesia, sapi Bali memiliki potensi yang sangat besar untuk dikembangkan (Sutarno dan Setyawan, 2015).
Sapi Bali menjadi primadona peternakan rakyat karena memiliki beberapa keunggulan yaitu, kemampuan adaptasi yang cukup baik pada berbagai kondisi lingkungan dan pakan yang kurang baik, kemampuan reproduksinya tinggi dan persentase karkas yang cukup tinggi. Sapi Bali merupakan plasma nutfah yang perlu dilestarikan karena merupakan asset nasional yang potensial untuk dikembangkan, karena memiliki 
keunggulan yang spesifik (Hikmawaty et al., 2014).

Masyarakat di Provinsi Jambi lebih dominan memelihara sapi Bali dibanding dengan sapi lainnya dan penyebarannya cukup merata hampir di semua kabupaten/kota dengan total populasi pada tahun 2012 sebesar 139.599 dan sebesar 161.667 pada tahun 2018 dengan rata rata kenaikan sebesar $2,28 \%$ per tahun, sedangkan pemotongan pada tahun 2012 sebesar 29.156 ekor dengan produksi daging $6.509 .125 \mathrm{~kg}$ dan pada tahun 2018 pemotongan meningkat menjadi 30.123 ekor namun daging yang dihasilkan hanya $4.690 .151 \mathrm{~kg}$ (DTPHP, 2018). Kondisi ini menunjukkan bahwa produktivitas sapi Bali yang ada di Provinsi Jambi mengalami penurunan dari tahun ke tahun.

Rendahnya produktivitas sapi Bali yang ada di Provinsi Jambi diduga akibat rendahnya pengetahuan petani dalam hal seleksi dan sistem pemeliharaan. Tinggi rendahnya produktivitas sapi Bali diantaranya dapat dilihat dari tingkat pertumbuhan, dengan melihat kenyataan tersebut maka upaya yang dapat dilakukan untuk meningkatkan produktivitas sapi Bali adalah mencari data dasar melalui karakterisasi karakteristik kuantitatif sapi Bali. Karakteristik kuantitatif adalah sifat yang dapat diukur, bernilai ekonomis dan dapat digunakan untuk seleksi dini. Karakter ini dipengaruhi oleh banyak pasang gen, bersifat aditif, dipengaruhi oleh lingkungan, serta dapat mencirikan ciri suatu bangsa (Mabrouk et al., 2010). Karakteristik fenotif dapat menggambarkan suatu proses pertumbuhan yang berkesinambungan dalam seluruh hidup hewan, merupakan indikator yang baik dalam menilai seekor ternak karena memiliki korelasi yang cukup dekat dengan karakter yang bernilai ekonomis.

Pengukuran karakteristik fenotip juga dapat membantu untuk memfasilitasi seleksi dan persilangan antara keturunan dan jenis ternak tergantung keragaman genetik (Kurnianto et al., 2013). Karakteristik fenotip diantaranya dapat dilihat dari karakteristik kuantitatifnya diantaranya adalah bobot badab (BB), pertambahan bobot badan (PBB) dan ukuran ukuran tubuh. Identifikasi karakteristik kuantitatif ini dapat dianalisis dengan analisis komponen utama (AKU) untuk menentukan penciri ukuran yang dipengaruhi oleh faktor lingkungan dan penciri bentuk oleh faktor genetik (Mahmudi et al., 2019).
Kegiatan-kegiatan karakterisasi fenotip ternak sapi Bali hingga saat ini belum banyak dilakukan. Di sisi lain karakterisasi ini menjadi dasar yang sangat penting untuk mengetahui struktur populasi, rencana konservasi yang efektif dan pemanfaatan sumber daya genetik serta perencanaan pengembangan sapi Bali di masa yang akan datang, apakah melalui seleksi dini atau program persilangan antara keturunan dan bangsa ternak sapi.

\section{MATERI DAN METODE}

Materi penelitian ini adalah ternak sapi Bali jantan dan betina umur $\mathrm{I}_{1}$ di Kabupaten Merangin dan Muaro Jambi. Peralatan yang digunakan adalah alat tulis, tongkat ukur,pita ukur,gelas ukur, timbangan dan kamera digital. Peubah yang diamati adalah karakteristik kuantitatif yaitu Bobot Badan (BB), Panjang Badan (PBB), Panjang Badan (PB), Tinggi Pundak (TP), Lingkar dada (LiD), Dalam Dada (DaD), Lebar Dada (LeD), Tinggi Pinggul (TPi), Lingkar kanon (LK) dan Lebar Pinggul (LPi) sapi Bali di Kabupaten Merangin dan Kabupaten Muaro Jambi Provinsi Jambi.

Metode penelitian ini adalah survei, dengan teknik pengumpulan sampel secara purpossive Random sampling. Jumlah sampel yang dikumpulkan di kedua Kabupaten sebanyak 120 ekor. Jumlah sampel masing masing kabupaten sebanyak 30 ekor jantan dan 30 ekor betina.

Data yang telah dikumpulkan dikelompokkan berdasarkan jenis kelamin dan selanjutnya dianalisis. Perbedaan PB, TP, LiD, $\mathrm{DaD}$, LeD, TPi, LK dan LPi sapi Bali jantan dan betina di Kabupaten Merangin dan Kabupaten Muaro Jambi Provinsi Jambi dianalisis dengan menggunakan uji t Gaspersz (2006). Persamaan ukuran diperoleh dari persamaan skor PC1) dan persamaan bentul diperoleh dari persamaan PC2 (Gaspersz, 2006).

\section{HASIL DAN PEMBAHASAN}

\section{Karakteristik Kuantitatif sapi Bali Jantan dan Betina}

Rata-rata karakteristik kuantitatif sapi Bali jantan dan betina meliputi; bobot badan, pertambahan bobot badan dan ukuran ukuran tubuh sapi umur $I_{1}$ di Kabupaten Merangin dan Kabupaten Muaro Jambi disajikan dapat dilihat pada Tabel 1. 
Tabel 1. Rataan karakteristik kuantitatif jantan dan betina sapi Bali umur $\mathrm{I}_{1}$ di Kabupaten Merangin dan Kabupaten Muaro Jambi Provinsi Jambi.

\begin{tabular}{clcccc}
\hline \multicolumn{2}{c}{ Karakteristik } & \multicolumn{2}{c}{ Merangin } & \multicolumn{2}{c}{ Muaro Jambi } \\
\cline { 3 - 6 } Fenotip & & Jantan & Betina & Jantan & Betina \\
\hline BB & $(\mathrm{kg})$ & $202,04 \pm 37,78^{\mathrm{a}}$ & $191,43 \pm 27,75^{\mathrm{b}}$ & $200,90 \pm 30,26^{\mathrm{a}}$ & $188,95 \pm 28,85^{\mathrm{b}}$ \\
PBB/hari & $(\mathrm{kg})$ & $0,36 \pm 0,06^{\mathrm{a}}$ & $0,32 \pm 0,05^{\mathrm{b}}$ & $0,35 \pm 0,07^{\mathrm{a}}$ & $0,31 \pm 0,05^{\mathrm{b}}$ \\
PB & $(\mathrm{cm})$ & $109,56 \pm 8,11^{\mathrm{a}}$ & $106,60 \pm 7,87^{\mathrm{b}}$ & $109,07 \pm 7,70^{\mathrm{a}}$ & $105,87 \pm 7,84^{\mathrm{b}}$ \\
TP & $(\mathrm{cm})$ & $108,03 \pm 6,51^{\mathrm{a}}$ & $104,30 \pm 6,20^{\mathrm{b}}$ & $107,68 \pm 4,31^{\mathrm{a}}$ & $103,50 \pm 7,23^{\mathrm{b}}$ \\
LD & $(\mathrm{cm})$ & $139,00 \pm 5,40^{\mathrm{a}}$ & $137,93 \pm 6,70^{\mathrm{b}}$ & $138,57 \pm 5,52^{\mathrm{a}}$ & $137,43 \pm 5,31^{\mathrm{b}}$ \\
DaD & $(\mathrm{cm})$ & $47,36 \pm 4,44^{\mathrm{a}}$ & $45,35 \pm 3,56^{\mathrm{b}}$ & $47,00 \pm 4,70^{\mathrm{a}}$ & $44,97 \pm 4,23^{\mathrm{b}}$ \\
LeD & $(\mathrm{cm})$ & $31,87 \pm 3,08^{\mathrm{a}}$ & $30,88 \pm 2,50^{\mathrm{b}}$ & $31,60 \pm 3,13^{\mathrm{a}}$ & $30,60 \pm 2,31^{\mathrm{b}}$ \\
TPi & $(\mathrm{cm})$ & $110,75 \pm 6,84^{\mathrm{a}}$ & $107,67 \pm 5,90^{\mathrm{b}}$ & $110,13 \pm 5,23^{\mathrm{a}}$ & $107,00 \pm 6,01^{\mathrm{b}}$ \\
LK & $(\mathrm{cm})$ & $14,21 \pm 1,31^{\mathrm{a}}$ & $13,04 \pm 0,97^{\mathrm{b}}$ & $14,16 \pm 1,21^{\mathrm{a}}$ & $12,92 \pm 1,16^{\mathrm{b}}$ \\
LP & $(\mathrm{cm})$ & - & $33,85 \pm 3,11^{\mathrm{b}}$ & - & $33,60 \pm 3,18^{\mathrm{b}}$ \\
\hline
\end{tabular}

Keterangan : Huruf yang beda pada baris yang sama kolom berbeda menunjukkan Beda Nyata $(\mathrm{P}<0,05)$ Panjang Badan (PB), Tinggi Pundak (TP), Lingkar dada (LiD), Dalam Dada (DaD), Lebar Dada (LeD), Tinggi Pinggul (TPi), Lingkar kanon (LK) dan Lebar Pinggul (LPi).

Tabel 1. menunjukkan secara berurutan bobot badan sapi Bali jantan Merangin > sapi Bali jantan Muaro Jambi $>$ sapi Bali betina Merangin dan > sapi Bali betina Muaro Jambi. Hasil analisis statistik uji beda rata menunjukkan bahwa Sapi Bali jantan Merangin berbeda tidak nyata $(\mathrm{P}>$ $0,05)$ dengan sapi Bali jantan Muaro Jambi. Sapi Bali jantan Merangin berbeda nyata $(\mathrm{P}<0,05)$ dengan sapi Bali betina Merangin dan sapi Bali betina Muaro Jambi. Sapi Bali Jantan Muaro Jambi berbeda nyata $(\mathrm{P}<0,05)$ dengan sapi Bali betina Merangin dan Sapi Bali betina Muaro Jambi. Sapi Bali betina Merangin berbeda tidak nyata $(\mathrm{P}>0,05)$ dengan sapi Bali betina Muaro Jambi. Kondisi menunjukkan bahwa tidak ada perbedaan bobot badan dan pertambahan bobot badan sapi bali jantan dan betina antara Kabupaten Merangin dan Kabupaten Muaro Jambi.

Bobot badan dan pertambahan bobot badan jantan berbeda nyata $(\mathrm{P}<0,05)$ lebih tinggi dibandingkan bobot badan dan pertambahan bobot badan betina baik di Kabupaten Muaro Jambi maupun Kabupaten Merangin. Hasil penelitian tidak jauh berbeda dengan hasil penelitian Hikmawaty et al. (2014) yang menyatakan bahwa bobot sapi Bali yang berasal dari Bali dan dari Sulsel jantan lebih tinggi dibandingkan yang betina pada umur yang sama. Adanya perbedaan bobot badan dan pertambahan bobot badan antara sapi Bali jantan dan sapi Bali betina diduga disebabkan oleh adanya perbedaan pengaruh hormon pertumbuhan. Menurut Hamdani et al. (2017) menyatakan bahwa tingkat pertumbuhan sapi jantan lebih tinggi dibandingkan sapi betina, karena pada sapi jantan produksi hormone androgennya lebih tinggi dan hormone ini merupakan hormone kelamin yang mengatur stimula pertumbuhan, terutama menstimulasi sintesis protein dalam otot. Selanjutnya Menurut Setiyono et al. (2017) bahwa pertumbuhan pada ternak jantan lebih cepat disebabkan oleh hormone steroid berupa hormone testosterone yang dihasilkan oleh testis.

\section{Koefisien Keragaman}

Koefisien keragaman karakteristik kuantitatif sapi Bali jantan dan betina umur $\mathrm{I}_{1}$ di Kabupaten Merangin dan Kabupaten Muaro Jambi disajikan pada Tabel 2.

Koefisien keragaman merupakan keberagaman antar populasi yang menunjukkan semakin tinggi tingkat keberagamannya maka populasi tersebut semakin beragam. Tabel 2 . menunjukkan bahwa koefisien keragaman sapi Bali jantan dan betina di Kabupaten Merangin antara 3,89 - 18,70\% dan di Kabupaten Muaro Jambi berkisar antara 3,86-18,80\%. Hasil ini menunjukkan bahwa koefisien keragaman sapi Bali jantan dan betina di Kabupaten Merangin dan Muaro Jambi hampir sama dan kisarannya relatif besar. Koefisien keragaman terbesar dari semua karakteristik fenotif baik di Kabupaten Merangin maupun Kabupaten Muaro Jambi jantan dan betina adalah pertambahan bobot badan dan bobot badan. 
Tabel 2. Koefisien keragaman (\%) karakteristik kuantitatif sapi Bali jantan dan betina umur $\mathrm{I}_{1}$ di Kabupaten Merangin dan Muaro Jambi.

\begin{tabular}{|c|c|c|c|c|c|}
\hline \multirow{3}{*}{$\begin{array}{c}\text { Karakteristik } \\
\text { Kuantitati }\end{array}$} & & \multicolumn{4}{|c|}{ Koefisien Keragaman } \\
\hline & & \multicolumn{2}{|c|}{ Merangin } & \multicolumn{2}{|c|}{ Muaro Jambi } \\
\hline & & Jantan & Betina & Jantan & Betina \\
\hline Bobot Badan & $(\mathrm{kg})$ & 18,70 & 14,50 & 15,06 & 15,27 \\
\hline Pertambahan Bobot Badan /hari & $(\mathrm{kg})$ & 15,32 & 14,87 & 18,80 & 17,32 \\
\hline Panjang Badan & $(\mathrm{cm})$ & 7,40 & 7,38 & 7,06 & 7,41 \\
\hline Tinggi Pundak & $(\mathrm{cm})$ & 6,03 & 5,95 & 4,00 & 6,99 \\
\hline Lingkar Dada & (cm) & 3,89 & 4,86 & 3,99 & 3,86 \\
\hline Dalam Dada & $(\mathrm{cm})$ & 9,37 & 7,84 & 9,99 & 9,41 \\
\hline Lebar Dada & $(\mathrm{cm})$ & 9,65 & 8,09 & 9,91 & 7,56 \\
\hline Tinggi Pinggul & $(\mathrm{cm})$ & 6,18 & 5,48 & 4,75 & 5,61 \\
\hline Lingkar Kanon & $(\mathrm{cm})$ & 9,22 & 7,41 & 8,58 & 8,98 \\
\hline Lebar Pinggul & $(\mathrm{cm})$ & - & 9,18 & & 9,46 \\
\hline
\end{tabular}

Koefisien keragaman pertambahan bobot badan jantan dan betina di Kabupaten Merangin yaitu $15,32 \%$ dan $14,87 \%$ dan di Kabupaten Muaro Jambi jantan dan betina $18,80 \%$ dan $17,32 \%$. Koefisien keragaman bobot badan di Kabupaten Merangin jantan dan betina yaitu $18,70 \%$ dan $14,50 \%$ dan di Kabupaten Muaro Jambi jantan dan betina yaitu $15,06 \%$ dan $15,27 \%$. Koefisien keragaman hasil penelitian cukup tinggi, jika dibandingkan dengan hasil penelitian Zurahmah dan The (2011) yang menyatakan bahwa koefisien keragaman bobot badan sapi Bali calon pejantan yaitu $12,01 \%$.

Selanjutnya hasil penelitian Hikmawati et al. (2014) menyatakan bahwa koefisien keragaman sapi Bali di BPTU sapi Bali Provinsi Bali jantan sebesar 30,30\% dan betina 15,65\%, Sulsel jantan 3,58\% dan betina 3,96\% dan di NTB jantan $1,24 \%$ dan betina $0,57 \%$. Tingginya keragaman bobot badan sapi Bali hasil penelitian ini membuka peluang untuk dilakukan seleksi. Noor (2008) menyatakan bahwa seleksi akan efektif dilakukan jika keragaman karakter yang diamati dalam populasi tinggi.

\section{Persamaan Ukuran dan Bentuk Tubuh Ternak Sapi Bali di Kabupaten Merangin dan Kabupaten Muaro Jambi}

Persamaan karakteristik kuantitatif penentu ukuran dan bentuk sapi Bali berdasarkan analisis komponen utama (AKU) di Kabupaten Merangin dan Kabupaten Muaro Jambi disajikan pada Tabel 3 .

Tabel 3. menunjukkan bahwa keragaman total komponen utama ke-1 yang berdasarkan ukuran kuantitatif di Kabupaten Merangin pada ternak jantan dan betina secara berurutan adalah 93,0\% dan 86,0 \% sedangkan di Kabupaten Muaro Jambi secara berurutan jantan dan betina $78,90 \%$ dan $86,20 \%$. Persentase ini merupakan proporsi keragaman terbesar diantara komponenkomponen utama yang diperoleh. Nilai vektor eigen terbesar yang didapatkan dalam persamaan ukuran sapi Bali jantan dan betina di Kabupaten Merangin dan Muaro Jambi lingkar dada (LD). Kondisi ini menunjukkan bahwa penciri ukuran adalah lingkar dada, alasannya karena memberikan kontribusi yang paling besar terhadap persamaan ukuran. Hal ini sesuai dengan pendapat Hikmawati et al. (2014) yang menyatakan bahwa lingkar dada merupakan faktor penentu bentuk sapi Bali hasil penelitiann di daerah BPTU Pulukan Bali, VBC Kabupaten Barru Sulses dan BPTHMT Serading NTB. Selanjutnya dinyatakan beberapa hasil penelitian menunjukkan bahwa secara umum penciri ukuran lingkar dada berkorelasi positif dan tertinggi dibandingkan ukuran tubuh lainnya pada sapi Bali (Hikmawati et al., 2018; Mahmudi et al., 2019).

Keragaman total pada komponen utama ke-2 yang disetarakan dengan bentuk di Kabupaten Merangin ternak jantan dan betina secara berurutan adalah $2,40 \%$ dan $5,40 \%$ sedangkan di Kabupaten Muaro Jambi secara berurutan jantan dan betina $8,70 \%$ dan 5,70 \%. Persentase ini adalah proporsi keragaman terbesar dibandingkan komponen-komponen utama lainnya. Vektor eigen terbesar yang diperoleh pada persamaan bentuk ternak sapi Bali jantan dan betina baik di dataran tinggi maupun dataran rendah adalah panjang badan $(\mathrm{PB})$ Kondisi ini menunjukkan bahwa panjang badan (PB) merupakan penciri bentuk pada sapi Bali karena memiliki kontribusi terbesar dalam persamaan bentuk. Hasil penelitian ini tidak jauh berbeda dengan hasil penelitian Hikmawati et al. (2014) yang menyatakan bahwa PB merupakan faktor penentu bentuk pada sapi Bali di Kabupaten Barru Sulsel. 
Tabel 3. Persamaan karakteristik kuantitatif sapi Bali berdasarkan analisis komponen utama (AKU) di Kabupaten Merangin dan Kabupaten Muaro Jambi

\begin{tabular}{|c|c|c|c|c|c|}
\hline Lokasi & & & Persamaan & $\begin{array}{l}\text { KT } \\
(\%) \\
\end{array}$ & $\lambda$ \\
\hline \multirow{6}{*}{$\begin{array}{l}\text { Kabupaten } \\
\text { Merangin }\end{array}$} & Jantan & & & & \\
\hline & Ukuran Tubuh & $=$ & 0,365 PB +0,380 TP +0.385 LD +0.378 DaD +0.381 LeD +0,380 Tpi +0,376 LK & 93,0 & 6,51 \\
\hline & Bentuk Tubuh & $=$ & 0.876 PB $-0,273 \mathrm{TP}+0.085 \mathrm{LD}-0,059 \mathrm{DaD}-0,108 \mathrm{LeD}-0,163 \mathrm{Tpi}-0,33 \mathrm{LK}$ & 2,40 & 0,17 \\
\hline & Betina & & & & \\
\hline & Ukuran Tubuh & $=$ & $0.352 \mathrm{~PB}+0.371 \mathrm{TP}+\mathbf{0 . 3 7 4} \mathbf{L D}+0.368 \mathrm{DaD}+0.361 \mathrm{LeD}+0,311 \mathrm{Tpi}+0,311 \mathrm{LK}+0,373 \mathrm{Lpi}$ & 86,0 & 6,88 \\
\hline & Bentuk Tubuh & $=$ & $\mathbf{0 . 3 6 7 P B}+\mathbf{0 , 1 5 5 T P}+0,213 \mathrm{LD}+0,178 \mathrm{DaD}+0,119 \mathrm{LeD}-0,633 \mathrm{Tpi}-0,627 \mathrm{LK}+0,141 \mathrm{Lpi}$ & 5,40 & 0,43 \\
\hline \multirow{6}{*}{$\begin{array}{c}\text { Kabupaten } \\
\text { Muaro } \\
\text { Jambi }\end{array}$} & Jantan & & & & \\
\hline & Ukuran Tubuh & $=$ & $0.298 \mathrm{~PB}+0.399 \mathrm{TP}+\mathbf{0 . 4 1 1 L D}+0.392 \mathrm{DaD}+0.385 \mathrm{LeD}+0,349 \mathrm{Tpi}+0,399 \mathrm{LK}$ & 78,90 & 5,52 \\
\hline & Bentuk Tubuh & $=$ & $\mathbf{0 . 9 0 2} \mathbf{P B}+\mathbf{0 , 0 2 8} \mathrm{TP}-0,121 \mathrm{LD}+0,012 \mathrm{DaD}-0.378 \mathrm{LeD}-0,114 \mathrm{Tpi}-0,123 \mathrm{LK}$ & 8,70 & 0,61 \\
\hline & Betina & & & & \\
\hline & Ukuran Tubuh & $=$ & $0.277 \mathrm{~PB}+0.351 \mathrm{TP}+\mathbf{0 . 3 7 4} \mathbf{L D}+0.372 \mathrm{DaD}+0.347 \mathrm{LeD}+0,373 \mathrm{Tpi}+0,362 \mathrm{LK}+0,362 \mathrm{Lpi}$ & 86,20 & 6,89 \\
\hline & Bentuk Tubuh & $=$ & $\mathbf{0 , 8 7 3}$ PB $-0,014 \mathrm{TP}-0,135 \mathrm{LD}+0,078 \mathrm{DaD}-0.424 \mathrm{LeD}-0,025 \mathrm{Tpi}-0,181 \mathrm{LK}+0,021 \mathrm{Lpi}$ & 7,50 & 0,60 \\
\hline
\end{tabular}




\section{KESIMPULAN}

Bobot badan, pertambahan bobot badan dan ukuran ukuran tubuh sapi Bali umur $\mathrm{I}_{1}$ jantan dan betina antara kedua Kabupaten Merangin dan Muaro Jambi relative sama. Faktor penentu ukuran tubuh sapi Bali di Kabupaten Merangin dan Muaro Jambi adalah Lingkar Dada (LD), sedangkan faktor penentu bentuk tubuh sapi Bali di Kabupaten Merangin dan Muaro Jambi adalah Panjang Badan (PB).

\section{DAFTAR PUSTAKA}

[DTPHP]. Dinas Peternakan dan Kesehatan Hewan Provinsi Jambi 2018. Statistik Peternakan dan Kesehatan Hewan Provinsi Jambi. Jambi

Gaspersz, V. 2006. Teknik Analisis dalam Penelitian Percobaan. Penerbit. Tarsito. Bandung.

Hamdani, M. D. I., K. Adhianto, Sulastri, A. Husni dan Renitasari. 2017. Ukuran-ukuran tubuh sapi Krui jantan dan betina di Kabupaten Pesisir Barat Lampung. Jurnal Ilmu Ternak 17 (2): 97-102.

Hikmawaty, A. Gunawan, R. R. Noor dan Jakaria. 2014. Identifikasi ukuran tubuh dan bentuk tubuh sapi bali di beberapa pusat pembibitan melalui pendekatan analisis komponen utama. Jurnal Ilmu Produksi dan Teknologi Hasil Peternakan 2 (1): 231 237.

Hikmawaty, B., A.T.B.A. Mahmud, dan A. Salam. 2018. Korelasi bobot badan dan variabelvariabel ukuran tubuh sebagai dasar seleksi calon induk sapi Bali. Agrovital (Jurnal Ilmu Pertanian Universitas Al Asyariah Mandar) 3 (1):11-13.
Kurnianto, E., S. Sutopo, E. Purbowati, E.T. Setiatin, D. Samsudewa, dan T. Permatasari. 2013. Multivariate analysis of morphological traits of local goats in Central Java,Indonesia. Iranian Journal of Applied Animal Science. 3 (2): 361-367.

Mabrouk, O., N. Sghair, G. Amor, B.A. Mohamed, dan B.A.E. Amel. 2010. Morphostructural growth according to the sex and birth mode and Relationship between body size and body weight of the local kids at the First five months of age in Tunisian arid area. Res J Biol Sci. 3:120127.

Mahmudi, R. Priyanto, dan Jakaria. 2019. karakteristik morfometrik sapi aceh, sapi po dan sapi bali berdasarkan Analisis Komponen Utama (AKU). Jurnal Ilmu Produksi dan Teknologi Hasil Peternakan 7 (1): $35-40$.

Noor, R. R. 2008. Genetika Ternak. Cetakan ke-4. PT. Penebar Swadaya. Jakarta.

Setiyono, A. H. A. Kusuma dan Rusman. 2017. Pengaruh bangsa, umur, jenis kelamin terhadap kualitas daging sapi potong di Daerah Istimewa Yogyakarta. Buletin Peternakan 41 (2) : 176-186.

Sutarno dan A. D. Setyawan. 2015. Genetic diversity of local and exotic cattle and heir cross breeding impact on the quality of Indonesian cattle. Biodiversitas 16 (2): $327-$ 354.

Zurahmah, N dan E. The. 2011. Pendugaan bobot badan calon pejantan sapi Bali menggunakan dimensi ukuran tubuh. Buletin Peternakan 5 (3): 160- 164. 